UDC 81

DOI https://doi.org/10.32838/2710-4656/2021.1-1/16

Rusakova O. O.

V. I. Vernadsky Taurida National University

\title{
THE ANALYSIS OF THE CRITERIA OF THE UKRAINIAN IELTS VARIANT
}

The article studies the correspondence of the international IELTS test to the criteria of the World Englishes Paradigm and contact variantology is discussed in this paper. English is the global contact language that is used in Europe as a Lingua Franca. English is one of the top studied foreign languages as in Ukraine so abroad because Ukraine is located in the European region and international relationships develop rapidly using the English Language. Receptive communicative competence such as Listening and Reading is analysed based on IELTS manuals. It is argued that grammatical and lexical structures in the training materials are selected adequately but the content reflects current migration processes, contexts of language use, and different accents of English from the viewpoint of native speakers in English-speaking countries.

Most of Ukrainians go to European and/or to Eastern countries it would be acceptable for them to hear how to speak in Italy, Germany, Portuguese, but not only in Britain. Even if the authors of the IELTS study materials included in the textbooks audio recordings in American, Australian or Canadian accents it is expected that Ukrainians would go to the USA, Australia or Canada, however, the reality differs. There would seem to be that the analysed materials are composed using the English variants however they are British. Just a small quantity of Ukrainians may go to Great Britain and will communicate in British accents there.

The analysed textbooks are formally modified because the authors included audio recordings in different English variants but only of the native speakers and text about the reality of the British, Australians, Americans, and Canadians. However, this formal approach is relevant neither to Ukrainian reality nor to the concept of the World Englishes Paradigm by which English speakers are classified by functional nativeness and genetic nativeness.

It is a fact that IELTS tasks are the same throughout the world for all modules on a test day. The test developers get the objectives and socio-professional information of applicants. However, this information does not influence the content of the exam. As a result, the analysis of the IELTS materials does not meet the aims and needs of test takers. The main presumption is that national IELTS test centers should introduce modifications according to the national and vocational status of test takers.

Key words: lingua franca, World Englishes Paradigm, English as a lingua franca, IELTS testing materials, local variants of English.

The core problem of the issue. This paper is devoted to a research at the intersection of sociolinguistics, the World Englishes Paradigm and methods of teaching the English Language (EL). There are tendencies in current sociolinguistics of EL which are directed at the study of localized usage norms of EL and language systems in the global linguistic situation of the late XX - early XXI century.

The polycentricity of EL in that period caused the appearance of a new field: the World Englishes Paradigm foundations were laid by the IndianAmerican sociolinguist Braj Kachru who divided English variants into three circles on a territorial basis. The Inner Circle includes countries where English is the native language; the Outer Circle includes post-colonial countries, where English is the second language and the Expanding Circle belongs to the countries where the English language is studied as a foreign language.

Analysis of recent research and publications. There are many sociolinguists who study World Englishes (WEs). E.g. Jennifer Jenkins (Great Britain), Sandra L. McKay (America), Barbara Seidlhofer (Austria), Anna Mauranen (Finland), Sandra Mollin (Sweden), Zoya Proshina (Russian) and many others study EL as an International contact Language which is some kind of English as a Lingua Franca (ELF).

Since the World Englishes Paradigm is a new research field there are many problems in the study methods, opposite views and contradictions in terminology. Researchers object against the idea of British and American English variants being used as an International Language because a language is 
shaped by its users and the quantity of the worldwide English users is superior to the quantity of native English speakers therefore it gives a reason to accept a new variant of English as a contact language or ELF.

The importance of the research is caused by the widespread status of European English (EE) as a second language in Ukraine, the processes of rapprochement with the European Union, where English is used as a contact language. In addition, there is a lack of the holistic and systematic coverage of problems of the regional European English variant and the Ukrainian variant coexistence, in connection with the functioning and teaching of a certain English version in the works of Ukrainian and foreign authors that we know.

The functioning of English as a second language in certain regions creates new characteristic features that can be used by the local society. In such language environment, a new variety of English requires further theoretical and pragmatic study. These issues are extremely interesting to research for the author of this paper who took the International English Language Testing System (IELTS) and is closely familiar with emerging Ukrainian English variant.

The aim of this article and the tasks. This paper aims to substantiate the necessity of the national diversification of the language competence of English as a second language in accordance with the trends of its functioning in the European linguistic continuum using the critical analysis of practical materials for IELTS.

In order to achieve this aim, the following tasks are performed:

1. To reveal the theoretical aspect of the criteria for identification of English as a second language in the European language situation from the position of the World Englishes Paradigm;

2. To determine variantological and functionalpragmatic characteristic of the methodological approaches in the IELTS test;

3. To analyse factual material of the training materials of the Listening Module and study materials;

4. To analyse factual material of the General Training Reading and the Academic Reading Module.

The outline of the main research material. The definition of the World Englishes Paradigm was introduced by Z. G. Proshina. The founder of this linguistics field was B. Kachru which is studied the current World English variants as a mother tongue for its native-speakers and as a foreign language for nonnative speakers and their functioning [2, p. 184-185].

Braj Kachru understood the fact that EL means thegloballanguage continuumanddifferentphenomena interacting within it. That is why he suggested that EL as a language for a huge number of people who are not native speakers is not standardized phonetically, grammatically and lexically by EL of Great Britain or the US [14, p. 21-22; 15, p. 19-20].

The classification of B. Kachru was based on the idea of English as a language that originally belonged to native speakers and was perceived by nonnative speakers as a second language and/or a learners' foreign language. Organising the variants of EL in the framework of the concept of "World Englishes", B. Kachru had proposed an original and functional model of English expansion [14, p. 11-36], in which its varieties are divided into three categories.

In B. Kachru's model, the World Englishes are located in three concentric circles, where the core, i.e. The Inner Circle includes the United States, the United Kingdom and other countries where EL is the national language. The variants of the Inner Circle have endonorms, i.e. their own standard used in all areas of society [5, p. 107]. B. Kachru called the Inner Circle norm-providing.

The second, the Outer Circle, embraces the countries which are associated with the British colonial empire historically. As Z. G. Proshina says, these variants have a wide range of social functions, including the function of interstate communication and the second official language of the country, supported by the institutions of the state, serving the administrative and legal, educational and cultural spheres [5, p. 107].

In the third, Expanding Circle countries are presented where English is not an official language but performs certain cultural and political functions focusing mainly on external communication serving as an instrument of interethnic and intercultural communication. EL appears in the speech of its users as a result of school education, but not as a result of learning in a natural communicative environment. B. Kachru calls these variants performance varieties [5, p. 107].

Until the second half of the XX century, EL of non-native speakers was still considered from the perspective of two samples, British or American. This idea was based on the theory that each language is the identifying property of its speakers who have a priority to establish its norms and standards [3, p. 84-85]. The linguists were interested in English as a Native Language (ENL) - British, American, Australian, etc. [1, p. $12-13,15 ; 6$; et al.; 17; 26; 28; 29 , p. $10-12 ; 31]$, and there was the opinion that the rest of the world study English as a Foreign Language (EFL) or English as a Second Language (ESL).

However, EL went beyond the limits not only of the original national borders but also beyond the English-speaking world, and the native speakers 
of new EL variants obtained the "proprietary rights" and legitimation of their regional norms and standards.

ELF functions as a contact language to meet communicative needs in international relationships of the speakers regardless of their being native or nonnative speakers. The current classification of English speakers by functional nativeness and genetic nativeness gives a new understanding of English pragmatic characteristics.

According to the model of B. Kachru's three circles, European countries are in the Expanding Circle, however, the number of English-speaking Europeans significantly rises every year. That is why researchers assume that the Expanding Circle is developing. It is obvious that English has become the Lingua Franca of Europe.

The most recent European researches show growth of the number of people who use English as a first language for communication with native speakers as well as a Lingua Franca with non-native speakers [17, p. 18]. The current language situation in European countries proves that bilingualism of English and another language has become popular since non-native speakers of English steadily increase in numbers [13].

The opening of the borders of post-soviet countries began the development of intercultural communication with almost all countries of the world. External factors such as international trade relationships and European integration influence the wide spread of EL as a second language in Ukraine.

Professor Laada M. Bilaniuk of Washington University states that since English is a global language it is used as a contact language for international relations between Ukraine and the worldwide English-speaking society. [10, p. 183]. However, this might be a controversial opinion judging by the fact that there are still many niches of social Ukrainian life where the use of English is inferior.

A Ukrainian researcher V. A. Radchuk observes significant changes in the Ukrainian language and considers that the reason of the recent process as free access to exchange information and Internet causing borrowing, code-switching, and interaction of several languages in one communicative area [7, p. 54-55].

There is widening of borrowings from English into Ukrainian advertising, media, trade and organization. Undoubtedly, it is possible to state that there is a great influence of English on the Ukrainian language.

Professor N. F. Klimenko distinguishes anglicisms and neo-borrowings. She qualifies them as barbarisms or foreign words used in the original phonetic and graphic form of the original language and not adapted in the Ukrainian language system [4, p. 13]. O. V. Babenko studies the process of assimilation of anglicisms in Ukrainian and claims that "when a word has been borrowed, it becomes integrated into the receiving language with varying extent." [9, p. 47].

Viktoriya Polyarush shows that among frequently borrowed words used in youth slang there are: 'message', 'nick' and 'to crack' in the IT area; 'party' (representing music and entertainment); 'trend' (fashion area); 'crazy', 'traffic' and 'boy-friend' 'sound' and 'trash"'. [17, p. 117].

The following examples that are presented by a Ukrainian researcher Y. O. Molotkina demonstrate the impact of borrowings upon the speech of Ukrainians. “ Наприклад, я приходжу в офіс, клінінг-менеджер захворіла. Окей. Я зустрічаю спічрайтера і копірайтера, вони мені говорять «фліп-чарт брудний, $\epsilon$ тільки вайтборд». Я говорю «Камон! Як ви можете воркати, коли у вас немає маст-хевстафу?» - Вибачте, а Ви зараз якою мовою говорили?» [11, p. 95].

According to Z. G. Proshuna, such deviations are gradually fixed in oral and written forms of discourse in different areas of activity turning into innovations. Some part of them is regarded as typical mistakes of the usage deviations indicate certain trends in changing the norms of EIL [6, p. 126].

Since a language is a dynamic process and English as a global language that is used in Ukraine as a contact language its impact on Ukrainian is obvious. In its turn, Ukrainian influences English. In accordance with the World English Paradigm, we may say that the Ukrainian variant of English is being formed and V. Y. Parashchuk calls it "Ukrlish" [8, p. 401].

Examples of English word usage in Ukraine demonstrate the influence of mental thinking on the attitude toward the English language in Ukrainian society.

In Ukrainian sometimes the trade centre is called a mall. In a huge trade complex, there are such names on signboards as "Megasport", "Intertop", "Moyo" for shops and departments. They are written in English. Also, there are transliterated English words in the names of firms on their signboards written by Ukrainian letters like "Electro Prom", "It-Poltava", "Auto Best Group", "Holod Max". These names may consist of Ukrainian words written in English letters. In Kyiv, there are such names on signboards of supermarkets, social buildings and firms like "Art Mall", "Lavina Mall", "Ocean Plaza", "Sky Mall", "Stereo Plaza", "Kiev Expo Plaza", "Fashion Cake".

These numerous examples testify that in Ukraine the attitude of people toward the English language 
is positive. Moreover, these facts suggest that the English language exercises significant influence on the life of Ukrainian society. In Ukraine, it is prestigious to study languages and primarily English.

Since English became a language of international communication and because of the increase of crosscultural relationships, a significant amount of people leave their home countries with the intention to study or work in foreign lands. Different Universities and organizations of all English-speaking countries, however, require a certain English level proficiency from all their applicants or candidates.

One of the famous international English language tests is IELTS that was developed in order to evaluate accurate candidates' English level.

The basis of the IELTS test has been set in two versions (Academic and General Training) and four modules (Listening, Reading, Writing, and Speaking) for each part of the test. The content of IELTS was not significantly changed since its formation. In 1995 specific writing and reading modules were assimilated into a single module for each [16].

In order to understand the standards which are used in principles of evaluation of the test results demonstrated by testing system (IELTS) it is necessary to characterise what CEFR is for IELTS. The advantages of CEFR, working principles, three directions, the aims, two dimensions, and six levels of English language knowledge are discussed.

This research examines textbooks by the scheme which aims at discussing the four points: theme of the audio recording, sentence structure and vocabulary.

To substantiate the necessity of diversification of the receptive communicative competences is one of the main tasks while analysing the materials. The comparative method is applied in order to examine these communication skills.

The study materials are presented as a series of textbooks including the Student's book, Workbook and Teacher's Book. The Student's Book consists of 12 units that include a review section after every second or third units. Since the receptive communicative skills are examined within this paper, the Listening and Reading parts of this study material are presented. According to the Teacher's Book to this course, the section Bridge to IELTS is a guidance which teaches learners how to perform types of the IELTS task. The Living to IELTS feature teaches key functional language related to the Speaking test [12, p. 5]. However, the Listening part of this textbook is related to this feature as well.

The grammar section focuses on meaning, use and form that are drawn from reading and listening texts $[12$, p. 4]. The parts of speech, morphological words structures and lexico-semantic groups are similar in both the reading part and in the listening part of this textbook.

The syntactical structures of the content of this study material mostly are not challenged because complex sentences are short and the proportion of them does not complicate the whole understanding of the materials. The content of this textbook is composed in accordance with the concept of the World Englishes Paradigm. However, the part of the text recording which was pronounced in the Brazil accent was repeated in British or Arabic accent in the Living to IELTS section.

The "Road to IELTS" Academic Reading Practice Test 1 by the British Council is analysed. This material consists of one original test of the Reading Module including three reading passages to demonstrate examination papers on a test day in order to introduce them to candidates in advance. The first page is composed of an instruction to candidates and some information about the tasks.

The themes of three texts vary from chronobiology, the theory about the triune brain to the process of the extraction of helium and its shortage. These texts are written in the types of non-fiction essays and are represented in semantic spheres such as medicine, nature, science. There is a variety of the types of sentences e.g.: Simple sentences: "This can take many forms." [18, p. 2], "The loss of helium on Earth would affect society greatly." $[18$, p. 11].

The analyses show that the themes of these texts are challenged sufficiently. If a person is not familiar with the 'Triune Brain' theory s/he might have challenge in understanding the whole content of the text and the questions.

The vocabulary that is used in all three texts is more formal, compared to its similarities in the questions. The first text consists of less special words, compared to others. However, there are two question types in the first and second reading passages, compared with the third passage.

To sum up, this training material is appropriate for the learners who would be able to understand the content of the test, see the principles of structuring and use their knowledge to prepare for the examination. However, these samples of the tests are not compiled according to the regional European English variant.

Conclusions. The present study was conducted in order to examine the training materials and textbooks which are used in Ukraine for preparation to the IELTS test. The research demonstrates that 1) the receptive communication competences (Listening and Reading) 
are presented in the training materials paying attention to the content, its themes, and types of sentences, grammar, morphological word structures, and vocabulary; 2) the growth of challenging in number of paragraphs and types of sentences in the texts of Reading section and transcripts of Listening sections is evaluated by the quantitative method; 3 ) the qualitative characteristics of tasks and exercises are discussed basing on the analysis of the texts and transcripts.

The analysis shows that the content of the materials is not appropriate. The difference is that the content of "Road to IELTS" consists of the British variant of English and "Bridge to IELTS" consists of other English variants as Australian, Brazil, Chinese, etc.

Different accents are included in these textbooks for those people who are going to China for work and to Great Britain, Australia or the United States and will meet there Chinese, Brazilians, etc. It is implied that candidates will study in Britain or in the USA.

It has found that the model of offering identical tasks does not take into account the concept of the World Englishes Paradigm. It is argued that the criteria of complex variantology could be rationally used for the preparation of Ukrainian test applicants and it would be appropriate to diversify the test tasks according to the national variants of English, in the context of the variants of English where the test is taken or considering a socio-professional purpose.

Thus, a new approach to the English testing system in Ukraine is presented. This method is based on the existence of the great variety of English variants and it is offered to take into account these English variants in testing procedures.

Therefore, taking into consideration the concept of the World Englishes Paradigm, we suggest that the content of the IELTS test should be modified considering the specific features of the Ukrainian variant of English and according to socio-professional purposes of applicants.

In order to achieve the modification of the IELTS test the following proposals are being brought forward: (1) According to the concept of the World Englishes Paradigm, the content of the Listening and Reading Modules should correspond to the national variants of English where the test is taken. Thus, for the Ukrainian candidates, texts and audio recordings should be in the Ukrainian variant of English.

(2) The audio recordings of the Listening Module should offer not only presentations of native English speakers in British and Australian accents but also include a range of German, Polish, Portuguese, Dutch, Chinese etc. accents of functional native speakers equally.

(3) The first four texts of the General Training should be about general themes and be the same for all candidates, but the fifth text should presuppose a right of choice of five options which cover the interest of the most spheres of Ukrainian job-seekers abroad, e.g., about housekeeping, agriculture, building, nursing and catering.

(4) The Listening module should be modified as the General Training and Academic Module with an account of the functional-pragmatic approach of a candidate's occupation and his/her aims which reflect the information from the application form.

Modification of the test IELTS according to the Ukrainian variant of EL, however, remains opened and could not be solved now. Since the Ukrainian variant of EL is not norm-formatting and the period of the formation of it is in a process of development. The perspective of the further study is the analysis of the formation criteria of the Ukrainian variant of EL.

\section{References:}

1. Домашнев А. И. Концепция национального варианта языка в трудах академика Г. В. Степанова. Филологические исследования : Памяти академика Г.В. Степанова. Москва : Наука, 1990. С. 4-17.

2. Словарь терминов межкультурной коммуникации / И. Н. Жукова и др. ; под ред. М. Г. Лебедько, 3. Г. Прошина. Москва : Флинта ; Наука, 2013. 632 с.

3. Кабакчи В. В. Английский язык межкультурного общения - новый аспект в преподавании английского языка. Иностранные языки в школе. 2000. № 6. С. 84-89.

4. Клименко Н. Ф. Динамічні процеси в сучасному українському лексиконі : монографія. Київ : ВД Дмитра Бураго, 2008.

5. Прошина 3. Г. Терминологическая сумятица в новом лингвистическом ракурсе: метаязык контактной вариантологии. Вестник Российского университета дружбы народов. Серия: Теория языка. Семиотика. Семантика. 2015. № 1. С. 105-117.

6. Прошина 3. Г. Учебники английского языка с позиции контактной вариантологии (World Englishes Paradigm). Межкультурная коммуникация: Взаимодействие языков, культур и менталитетов : монография : к юбилею проф. М. Г. Лебедько ; под ред. О. В. Николаевой. Владивосток : Дальневост. федерал. ун-т., 2014. С. 220-230.

7. Радчук В. А. Мова в Україні: стан, функції, перспективи. Мовознавство. 2002. № 2-3. С. 39-45. 
8. Паращук В. Ю. Типологія варіантів сучасної англійської мови в соціальній комунікації. Наукові записки Серія: Філологічні науки (мовознавство). Кіровоград, вид. Лисенко В. Ф. 2015. Вип. 137. С. 396-402.

9. Babenko O. V., Ilin S. V. Processes of assimilation of English borrowings in Modern Ukrainian. Науковий вісник Національного університету біоресурсів $i$ природокористування України. Серія «Філологічні науки». 2016. Р. 46-52.

10. Bilaniuk L. M. Contested tongues: language politics and cultural correction in Ukraine. Ithaca, N.Y. : Cornell University Press, 2005. P. 230.

11. Dizel Show «Проблеми Української Мови». 2016. URL: https://www.youtube.com/ watch?v=ukonBMs0WM0

12. Harrison L. Bridge to IELTS. Teacher's Book. National Geographic Learning, Cengage Learning, 2012. 159 p.

13. Hoffmann C. An introduction to bilingualism. London : Routledge, 1991. 368 p.

14. Kachru B. B. Standards, codification and sociolinguistic realism: The English language in the outer circle. English in the world: Teaching and learning the language and literatures; eds. R. Quirk, H. Widdowson. Cambridge : Cambridge University Press, 1985. P. 11-36.

15. Kachru B. B. The Alchemy of English: The Spread, Functions and Models of Non-Native Englishes. Oxford : Pergamon Press, 1986. 200 p.

16. Manhattan Review. History of the IELTS. URL: https:/www.manhattanreview.com/ielts-history/ (access: 21.12.2018).

17. Polyarush V. The influence of English on Ukrainian, with a focus on the language of youth : thesis ... MA : Middle East Technical University. Çankaya/Ankar, 2010. 215 p.

18. Road to IELTS Academic Reading Practice Test 1. URL: https://www.roadtoielts.com/ (access: 10.02.2021).

\section{РУсаКова О. О. АНАЛІЗ КРИТЕРІЇВ УКРАЇНСЬКОГО ВАРІАНТУ ТЕСТУ IЕLTS}

У статті аналізується відповідність міжнародної системи тестування англійської мови IELTS критеріям конщепиії варіантів світової англійської мови (АМ) та контактної варіантології. Рецептивні види мовленнєвої діяльності, такі як аудіювання та читання, характеризуються граматичними й лексичними структурами AM, представленими в підручниках IELTS, які формально відповідають сучасним міграційним процесам, контекстам використання АМ і різним акцентам АМ з позиції носія мови в англомовних країнах, але склад усіх матеріалів не відповідає розвитку локальних варіантів АM, зокрема українського варіанту. Запропоновані шляхи оптимізації тесту IELTS з урахуванням національного та професійного статусу іспитників.

Більшість українців їдуть до європейських та/або східних країн, для них було би прийнятно чути, як говорити в Італії, Німеччині, Португалії, але не лише у Великобританії. Навіть якщо автори навчальних матеріалів IELTS включені до аудіозаписів підручників з американськими, австралійськими чи канадськими акцентами, очікується, що українці поїдуть до США, Австралії чи Канади, проте реальність відрізняється. Проаналізовані підручники офіційно змінені, оскільки автори включили аудіозаписи в різних варіантах англійської мови, але лише носіїв мови та текст про реальність британиів, австралійців, американиів та канадців. Однак ией формальний підхід не має відномення ні до украӥнської дійсності, ні до конщепиії контактної варіантології, згідно з якою носії англійської мови класифікуються за функиіональною природою та генетичною природою.

Фактом є те, що завдання IELTS однакові у всьому світі для всіх модулів у тестовий день. Розробники тестів отримують ичілі та сочиіально-професійну інформаџію заявників під час реєстрачії. Однак ия інформачія не впливає на зміст іспиту. Здається, аналізовані матеріали складаються з використанням англійських варіантів, проте вони британські. Лише невелика кількість украйнців може поӥхати до Великобританії та спілкуватись там із британськими акиентами.

Як результат, аналіз матеріалів IELTS не відповідає иілям та потребам учасників тестування. Основне припущення полягає в тому, що національні тестові иентри IELTS повинні вносити зміни відповідно до наиіонального та професійного статусу учасників тестування.

Ключові слова: лінгва франка, контактна варіантологія англійської мови, міжнародна система тестування IELTS, AM як лінгва франка, локалізовані варіанти AM. 